\title{
Oxygen introduction during extraction and the improvement of antioxidant activity of essential oils of basil, lemon and lemongrass
}

\author{
Daniele de Freitas Ferreira ${ }^{1}$ Flávia Michelon Dalla Nora ${ }^{1}$ \\ Bruna Nichelle Lucas ${ }^{1}$ Cristiano Ragagnin de Menezes ${ }^{1}$ Alexandre José Cichoski ${ }^{1}$ \\ Sandro Rogério Giacomelli ${ }^{2}$ Roger Wagner ${ }^{1}$ Juliano Smanioto Barin ${ }^{*}$
}

${ }^{1}$ Departamento de Tecnologia e Ciência dos Alimentos, Universidade Federal de Santa Maria (UFSM), 97105-900, Santa Maria, RS, Brasil. E-mail: juliano@ufsm.br. "Corresponding author.

${ }^{2}$ Departamento de Ciências Exatas e da Terra, Universidade Regional Integrada do Alto Uruguai e Missões (URI), Frederico Westphalen, RS, Brasil.

ABSTRACT: Essential oil extraction is commonly carried out by using the hydrodistillation method, which is described in official compendia of food quality control and medicinal plants. Despite the widespread use of this method, few studies have evaluated the effect of the atmosphere change during extraction on the composition and antioxidant activity of essentials oils. Therefore, a study of oxygen introduction influence during the extraction of essential oils from basil, lemongrass and lemon by hydrodistillation was performed. Total amount of oxygenated compounds (e.g., linalool, camphor, $\alpha$-terpineol, neral, geranial, eugenol and $\alpha$-muurolol) increased for all essential oils extracted under oxygen flow. Antioxidant activity evaluated by using the ORAC method significantly increased $(P<0.0001)$ with oxygen from 618 to 906,355 to 613 and 72 to $262 \mu \mathrm{mol}$ Trolox $\mathrm{g}^{-1}$ oil for basil, lemongrass and lemon, respectively. Therefore, the simple modification proposed could be considered a suitable alternative to obtain essential oils with higher antioxidant activity.

Key words: antioxidant activity, chromatography, ORAC, volatile oil.

Introdução de oxigênio durante a extração e aumento da atividade antioxidante de óleos essenciais de manjericão, limão e capim-limão

RESUMO: A extração de óleos essenciais é comumente realizada pelo método de hidrodestilação, o qual é descrito em compêndios oficiais para o controle de qualidade de alimentos e plantas medicinais. Apesar do largo uso deste método de extração, poucos estudos têm sido propostos para avaliar o efeito da mudança da atmosfera durante a extração na composição e atividade antioxidante de óleos essenciais. Portanto, um estudo sobre a influência da introdução de oxigênio na extração de óleos essenciais de manjericão, capim-limão e limão foi realizado. A quantidade total de compostos oxigenados (e.g., linalol, cânfora, $\alpha$-terpineol, neral, geranial, eugenol e $\alpha$-muurolol) aumentou em todos os óleos essenciais extraídos com oxigênio. A atividade antioxidante avaliada pelo método ORAC aumentou significativamente $(P<0,0001)$ com a introdução de oxigênio, variando de 618 para 906, de 355 para 613 e de 72 para $262 \mu m o l$ Trolox g $^{-1}$ óleo essencial de manjericão, capim-limão e limão, respectivamente. Portanto, a modificação simples proposta mostrou-se uma alternativa adequada para obtenção de óleos essenciais com maior atividade antioxidante.

Palavras-chave: atividade antioxidante, cromatografia, ORAC, óleo volátil.

\section{INTRODUCTION}

The demand of consumers for natural products as substitutes for synthetic additives has increased given that synthetic substances can result in adverse effects to human health. In this way, several natural compounds have been studied as food additives, including essential oils, which are a promising alternative for food industries that is being recognized by regulatory bodies (e.g., Food and Drug Administration, FDA, USA) as safe substances (ALFONZO et al., 2017). Essential oils are secondary metabolites with a strong odoriferous impact obtained through different parts of several aromatic plants including leaves, flowers, roots, seeds, fruits and peels. These oils are composed of a complex mixture of volatile compounds, mainly monoterpenes and sesquiterpenes, which can be classified as hydrocarbons or oxygenated ones (DJOUAHRI, BOUDARENE, \& MEKLATI, 2013). Oxygenated compounds play an important role in essential oils, and they are often responsible for the main biological properties. However, their amount is closely related to the extraction method used (AMORATI et al., 2013). Antioxidant and antimicrobial activity of essential oils are often reported, and they have been used for the improvement of the quality and shelflife of food such as fish, meat, cheese and minimally processed fruits and vegetables (AMORATI et al., 2013; PATEL, 2015). In addition, essentials oils 
can be used in active food packaging to reduce the oxidation process and extend the shelf-life of perishable products (MAISANABA et al., 2017).

Extraction of essential oils is a critical step because, depending on the conditions used for extraction (e.g., heating, amount of plant material, atmosphere composition, time for extraction), the composition of essential oils could change with impact on their antioxidant and antimicrobial activities (DJOUAHRI et al., 2013). Hydrodistillation (HD) is one of the most used methods for essential oil extraction, and it is recommended in official compendia of quality control of aromatic plants (Brazilian Pharmacopeia, 2010; IAL, 2004). This method is based on the heating of plant material with water, and the essential oil is carried out together with the water vapor and further condensed (and separated from water) into a Clevenger-type apparatus (ORIO et al., 2012).

In this way, HD could be considered to be a simple process for essential oil extraction, and the main modifications for the improvement of extraction (e.g., reduction in extraction time) have focused on the use of microwaves for heating (CHEMAT \& CRAVOTTO, 2013). Despite the good results obtained regarding the reduction in extraction time and energy consumption, the use of microwaves requires dedicated instruments, which generally have a high cost of acquisition and limited widespread application in laboratories. In this research, a simple modification was made to conventional HD extraction in order to obtain essential oil from different plants with higher antioxidant activity by the introduction of oxygen gas during extraction. In this way, essential oils from lemon peel and leaves of basil and lemongrass were extracted with and without addition of oxygen. Chemical composition of essential oils was then evaluated by gas chromatography (GC) and antioxidant activity results were obtained by using the oxygen radical absorbance capacity (ORAC) method.

\section{MATERIALS AND METHODS}

\section{Plants, chemicals, materials and instrumentation}

The lemon (Persian lime) peels and basil (Ocimum basilicum) and lemongrass (Cymbopogon citratus) leaves were obtained in May 2016 from local plants and stored at $-18^{\circ} \mathrm{C}$ for a week until the end of the extraction experiments. Samples of basil and lemongrass were ground in a knife mill at 5,400rpm for $3 \mathrm{~s}$ and lemon peels at $13,500 \mathrm{rpm}$ for $5 \mathrm{~s}$ in order to avoid the rupture of structures that retain essential oils in the plants (TISCHER et al., 2017). Anhydrous sodium sulfate P.A. (99\%, Impex, Brazil) was used to dry the essential oil after extraction. Deionized water for distillation and hexane for the dilution of essential oils for GC analysis were used. Chromatographic grade helium, hydrogen, nitrogen and oxygen (White Martins, Brazil) were used in the GC-FID and GCMS determination, and oxygen was also used in HD. All reagents for the evaluation of the antioxidant activity of ORAC were of analytical grade (SigmaAldrich, USA).

A Clevenger apparatus equipped with a $1 \mathrm{~L}$ glass flask was used for the extraction of essential oils by HD, with an adaptation for oxygen introduction (Figure 1). Samples were ground using a knife mill (model MA 630/1, Marconi, Brazil). Compounds presented in essential oils were determined using a gas chromatograph (Varian Star 3400CX, USA) equipped with a flame ionization detector and a fused silica capillary column RTX-5MS $(30 \mathrm{~m} \times 0.25 \mathrm{~mm}$ i.d. $\times$ $0.25 \mu \mathrm{m}$ film thickness, Restek Corporation, USA). A mass spectrometry chromatograph Shimadzu Q-2010 Plus (GC-MS, Shimadzu Corporation, Japan) equipped with a fused silica capillary column ZB$5 \mathrm{MS}(30 \mathrm{~m} \times 0.25 \mathrm{~mm}$ i.d. $\times 0.25 \mu \mathrm{m}$ film thickness, Phenomenex, USA) was used for identification of substances. Antioxidant activity was measured by fluorimetric assay for ORAC and carried out using SpectraMax M5 (Molecular Devices, USA).

\section{$H D, G C$ analysis and antioxidant activity determination Ground leaves and peels (50g) were mixed} with $500 \mathrm{~mL}$ of water in the glass flask, with further heating for $3 \mathrm{~h}$ in a Clevenger-type apparatus. A polytetrafluoroethylene (PTFE) tube (3mm of internal diameter) was adapted through one of the necks of the flask using silicon rubber for oxygen introduction (Figure 1). Oxygen flow rate was maintained constant at $0.7 \mathrm{~L} \mathrm{~min} \mathrm{~m}^{-1}$ during all extractions, but a purge step was used previously, using $2 \mathrm{~L} \mathrm{~min}{ }^{-1}$ oxygen for $5 \mathrm{~min}$. The essential oil was separated by density and was collected and dried using anhydrous sodium sulfate to eliminate traces of moisture. The extracted essential oils were kept at $4^{\circ} \mathrm{C}$ until further analysis.

Composition of essential oil was determined by GC-FID using $1 \mu \mathrm{L}$ of diluted sample in hexane $(1: 100)$. Equipment was operated in split mode $(1: 20)$ at $250^{\circ} \mathrm{C}$ for both injection and detection. For evaluation of the basil essential oil, the temperature program was started at $35^{\circ} \mathrm{C}$ for $5 \mathrm{~min}$, increasing to $90^{\circ} \mathrm{C}$ at $4^{\circ} \mathrm{C} \mathrm{min} \mathrm{min}^{-1}$ and to $150^{\circ} \mathrm{C}$ at $31^{\circ} \mathrm{C} \mathrm{min}^{-1}$, and finally to $220^{\circ} \mathrm{C}$ at $20^{\circ} \mathrm{C} \mathrm{min} \mathrm{min}^{-1}$; it was then held for $1 \mathrm{~min}$ at this temperature. For the lemongrass and lemon peel 


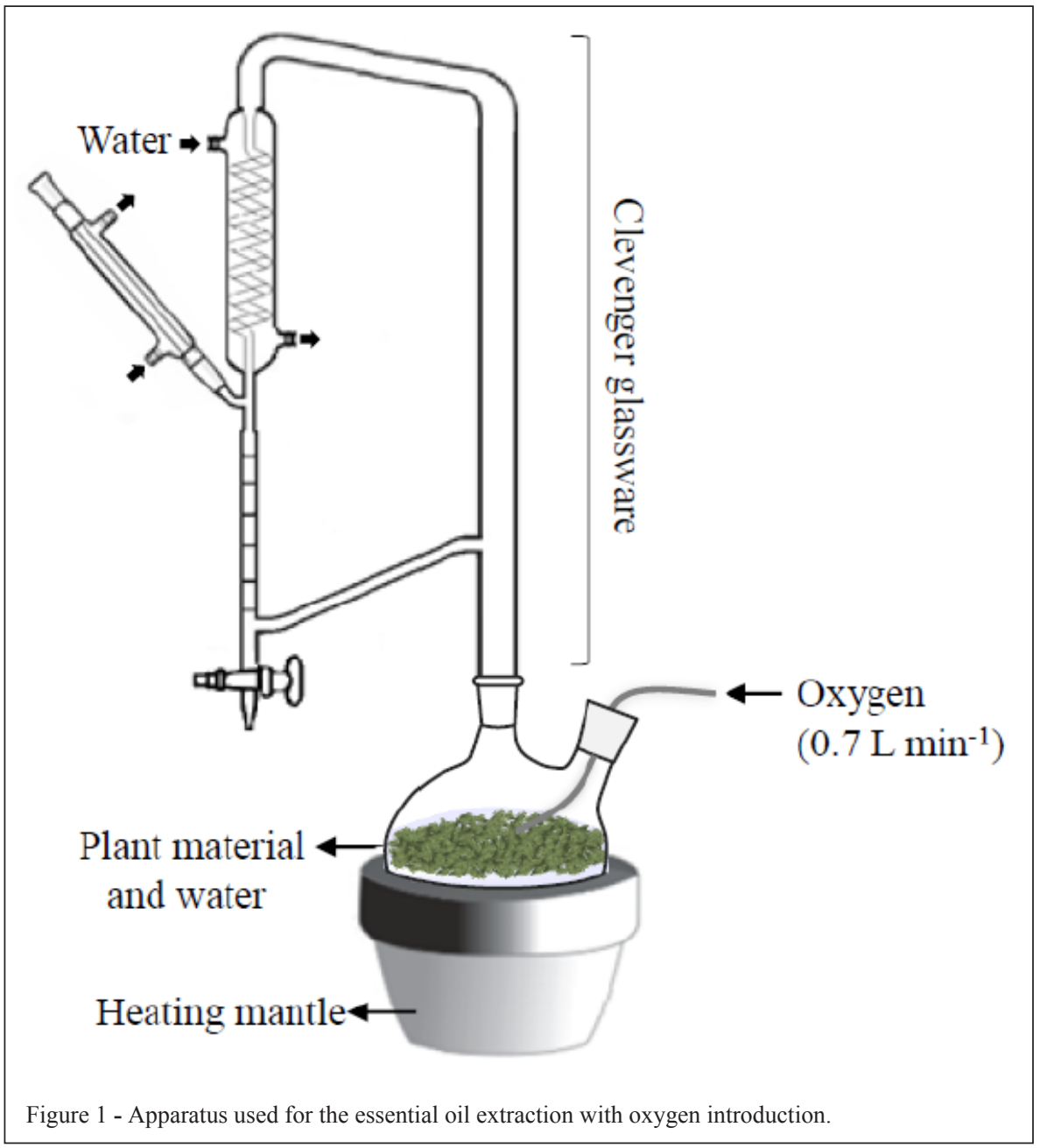

essential oils, the column temperature started at $35^{\circ} \mathrm{C}$ for $5 \mathrm{~min}$, increasing to $100^{\circ} \mathrm{C}$ at $2^{\circ} \mathrm{C} \mathrm{min}^{-1}$ and thereafter to $220^{\circ} \mathrm{C}$ at $20^{\circ} \mathrm{C} \mathrm{min}^{-1}$, held for $5 \mathrm{~min}$. Hydrogen was used as carrier gas and flow rate and pressure values were $2.5 \mathrm{~mL} \mathrm{~min}^{-1}$ and $15 \mathrm{psi}$, respectively. Quantification of compounds was performed based on the normalization of the peak areas. Identification was performed by GC-MS using the same conditions as GC-FID, but using helium instead of hydrogen. Temperature of GCMS interface and ionization source was fixed at $250^{\circ} \mathrm{C}$ using the electron ionization mode $(+70 \mathrm{eV})$ and monitoring ions between 35 to $350 \mathrm{~m} \mathrm{z}^{-1}$. In order to calculate the Kovats Index (KI) of volatile compounds, a homologous series of alkanes $\left(\mathrm{C}_{6}-\right.$ $\mathrm{C}_{24}$ ) was analyzed using the same chromatographic conditions. In addition, the identification of compounds was confirmed by a comparison with mass spectra available in the National Institute of Standards and Technology library (NIST 02, Gaithersburg, MD, USA) and also with the calculated KI reported in the literature.

Antioxidant activity determination by using the ORAC method was performed based on the method of OU et al. (2001). This method is based on the scavenging activity of essential oils against peroxyl radicals generated from the AAPH radical inductor. For this purpose, $25 \mu \mathrm{L}$ of diluted essential oil or Trolox reference solutions was added into potassium phosphate buffer $\left(75 \mathrm{mmol} \mathrm{L}^{-1}, \mathrm{pH} 7.4\right)$ and incubated at $37^{\circ} \mathrm{C}$ for $10 \mathrm{~min}$ in microplates; $150 \mu \mathrm{L}$ of fluorescein solution $\left(81 \mathrm{nmol} \mathrm{L}^{-1}\right)$ was used as an indicator and $25 \mu \mathrm{L}$ of AAPH $\left(152 \mathrm{mmol} \mathrm{L}^{-1}\right)$ was added as peroxyl radical generator. Using wavelengths of $485 \mathrm{~nm}$ for excitation, fluorescence was measured in $528 \mathrm{~nm}$ at $37^{\circ} \mathrm{C}$ for $120 \mathrm{~min}$. Antioxidant activity was determined considering the area under curve (AUC) values and Trolox curve $\left(0-96 \mu \mathrm{mol} \mathrm{L}^{-1}\right)$. 
All extractions as well as chromatographic and antioxidant activity analysis were carried out in triplicate and the results were statistically evaluated using the Student's $t$-test at 5\% confidence level with the software Statistica v. 7.0 (Statsoft, Tulsa, USA, 2004).

\section{RESULTS AND DISCUSSION}

Oxygen introduction during extraction process presented little influence on yield of the essential oils evaluated. For lemongrass, no differences were observed for extractions with and without oxygen, and an essential oil yield of $1.49 \%$ was obtained. For the basil and lemon essential oils, a slight reduction in yield was observed, from $2.75 \%$ and $5.25 \%$ (without oxygen) to $2.58 \%$ and $4.69 \%$ (with oxygen) for basil and lemon, respectively. In relation to the chemical composition, essential oils extracted with and without oxygen introduction presented the same number of volatile substances, but with changes in the amount of some compounds, as can be seen in table 1 .

A total of 16 monoterpenes were reported in the essential oil from basil, and in general oxygen addition resulted in a decrease in hydrocarbon monoterpenes, reaching an amount of $8.87 \%$ in conventional $\mathrm{HD}$ and $2.33 \%$ in $\mathrm{HD}$ with oxygen introduction. In this case, a significant reduction in $\beta$-pinene, $\alpha$-pinene and limonene was observed. In relation to oxygenated monoterpenes in basil, a higher amount was obtained using oxygen introduction during extraction $(78.32 \%)$ in comparison to conventional HD (without oxygen, $72.98 \%$ ). Changes were observed mainly for linalool and eugenol, but it was also important for camphor and $\alpha$-terpineol. For the sesquiterpenes of basil, effect of oxygen introduction was lower in relation to monoterpenes, but it presented a slight decrease in hydrocarbons (from $14.04 \%$ to $13.28 \%$ ) and also an increase in oxygenated ones (from $4.02 \%$ to $6.07 \%$ ).

In lemongrass essential oil, only monoterpenes were identified and the use of oxygen resulted in a strong reduction in hydrocarbon monoterpenes in comparison to conventional HD without oxygen (from $14.70 \%$ in HD to $7.05 \%$ for HD plus oxygen). In relation to the oxygenated compounds of the lemongrass essential oil, it is important to note the higher amount of citral for extraction with oxygen, which is considered to be the most important substance for lemongrass essential oil. This compound is represented by the isomers neral and geranial, which are mainly responsible for the odor and biological properties of oil. In addition, it has been considered to be a building block for fine chemicals (GANJEWALA et al., 2012). Thus, oxygen introduction increased the geranial and neral amount from $34.41 \%$ and $49.82 \%$ to $36.58 \%$ and $55.10 \%$, respectively. Therefore, the use of oxygen during extraction allowed the production of more valuable compounds in the lemongrass essential oil.

For the lemon peel essential oil, the amount of hydrocarbon monoterpenes decreased (from $91.43 \%$ to $86.36 \%$ ) by the introduction of oxygen, mainly due to the reduction in limonene, $\beta$-pinene and $\alpha$-pinene. These results are in agreement with NGUYEN et al. (2009) that demonstrated the high susceptibility of these compounds to oxidation under an oxygen atmosphere. Lemon essential oil is represented by a small amount of oxygenated compounds, but the oxygen addition almost doubled the amount of these compounds (from $6.59 \%$ to $11.43 \%$ ). In this case, a significant increase in $\alpha$-terpineol, neral and geranial (citral) was obtained with the oxygen. This is an important feature because citral was described as one of the major contributors to the aroma of lemon oil (NGUYEN et al., 2009).

According to the results obtained, the introduction of oxygen during extraction increased the concentration of oxygenated compounds in the essential oils. Studies have demonstrated that the antioxidant and antimicrobial capacity of essential oils are directly related to oxygenated terpenes. For this reason, these compounds could be considered to be more valuable (AMORATI et al., 2013) and the antioxidant activity evaluation of oils was performed (Figure 2) by using the ORAC method (BENTAYEB et al., 2014). As shown in figure 2, extraction process in an oxygenated atmosphere resulted in the highest antioxidant activity for all analyzed essential oils. The antioxidant activity of the basil essential oil increased from 618 to $906 \mu \mathrm{mol}$ Trolox $\mathrm{g}^{-1}$ oil, which could be explained by chemical modifications of the essential oil promoted by oxygen addition. Oil extracted with oxygen presented higher amounts of linalool and eugenol, which are compounds reported in the literature as highly antioxidant (GÜLÇIN, 2011; DUARTE et al., 2016). For lemongrass, an increase in antioxidant activity with oxygen addition was also observed, with values of 355 and $613 \mu \mathrm{mol}$ Trolox $\mathrm{g}^{-1}$ oil for conventional HD without and with oxygen, respectively. For lemon essential oil, antioxidant activity improved to a high extent, considering that generally this essential oil presented low antioxidant potential. Oxygen introduction in this case improved antioxidant activity four times, from 72 to $262 \mu \mathrm{mol}$ 
Table 1 - Volatile compounds of basil, lemongrass and lemon essential oil (\%) obtained by GC-FID after extraction using conventional hydrodistillation without oxygen (HD) and with oxygen $\left(\mathrm{HD}+\mathrm{O}_{2}\right)$.

\begin{tabular}{|c|c|c|c|c|c|c|c|c|}
\hline \multirow{2}{*}{ Volatile compounds } & \multirow{2}{*}{$\mathrm{RI}^{1}$} & \multirow{2}{*}{$\mathrm{RI}^{2}$} & \multicolumn{2}{|c|}{--------------Basil------------- } & \multicolumn{2}{|c|}{--------Lemongrass--------- } & \multicolumn{2}{|c|}{---------Lemon--------. } \\
\hline & & & HD & $\mathrm{HD}+\mathrm{O}_{2}$ & HD & $\mathrm{HD}+\mathrm{O}_{2}$ & HD & $\mathrm{HD}+\mathrm{O}_{2}$ \\
\hline \multicolumn{9}{|c|}{ Hydrocarbon monoterpenes---- } \\
\hline$\alpha$-thujene & 926 & 925 & - & - & - & - & $0.64^{*}$ & $0.28^{*}$ \\
\hline$\alpha$-pinene & 935 & 936 & $1.47^{*}$ & $0.05^{*}$ & - & - & $2.37^{*}$ & $1.03^{*}$ \\
\hline Camphene & 954 & 954 & $1.08^{*}$ & $0.13^{*}$ & - & - & - & - \\
\hline$\beta$-pinene & 978 & 978 & $2.23^{*}$ & $0.41^{*}$ & - & - & $12.46^{*}$ & $7.87^{*}$ \\
\hline Myrcene & 992 & 992 & $1.15^{*}$ & $0.37^{*}$ & $14.10^{*}$ & $6.60^{*}$ & $1.51^{*}$ & $1.31^{*}$ \\
\hline p-cymene & 1026 & 1026 & - & - & 0.02 & 0.06 & - & - \\
\hline Limonene & 1029 & 1029 & $1.89^{*}$ & $0.79^{*}$ & 0.02 & 0.02 & 58.00 & 58.64 \\
\hline (Z)- $\beta$-ocimene & 1044 & 1041 & $0.23^{*}$ & $0.12^{*}$ & $0.34^{*}$ & $0.22^{*}$ & - & - \\
\hline (E)- $\beta$-ocimene & 1056 & 1055 & - & - & $0.22^{*}$ & $0.15^{*}$ & - & - \\
\hline$\gamma$-terpinene & 1064 & 1063 & $0.26^{*}$ & $0.13^{*}$ & - & - & $15.7^{\mathrm{a}}$ & 16.36 \\
\hline$\alpha$-terpinolene & 1090 & 1089 & $0.56^{*}$ & $0.33^{*}$ & - & - & $0.73^{*}$ & $0.87^{*}$ \\
\hline Total & & & 8.87 & 2.33 & 14.70 & 7.05 & 91.43 & 86.36 \\
\hline \multicolumn{9}{|c|}{ 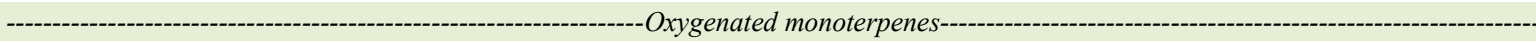 } \\
\hline 1,8-cineol & 1036 & 1035 & $22.21^{*}$ & $9.06^{*}$ & - & - & - & - \\
\hline Linalool & 1102 & 1103 & $22.45^{*}$ & $29.41^{*}$ & $0.68^{*}$ & $0.76^{*}$ & - & - \\
\hline$\beta$-citronellol & 1143 & 1228 & - & - & $0.39^{*}$ & $0.51^{*}$ & - & - \\
\hline Camphor & 1176 & 1177 & $13.70^{*}$ & $16.00^{*}$ & - & - & - & \\
\hline 4-terpineol & 1190 & 1184 & 0.56 & 0.62 & - & - & $0.29^{*}$ & $0.62^{*}$ \\
\hline$\alpha$-terpineol & 1229 & 1203 & $2.53^{*}$ & $3.49^{*}$ & - & - & $0.48^{*}$ & $0.98^{*}$ \\
\hline Nerol & 1230 & 1228 & $0.02^{*}$ & $0.04^{*}$ & - & - & - & - \\
\hline Neral & 1240 & 1240 & - & - & $34.41^{*}$ & $36.58^{*}$ & $1.77^{*}$ & $3.01^{*}$ \\
\hline Geranial & 1268 & 1270 & - & - & $49.82^{*}$ & $55.10^{*}$ & $2.45^{*}$ & $4.20^{*}$ \\
\hline Bornyl acetate & 1287 & 1286 & $0.11^{*}$ & $0.16^{*}$ & - & - & - & - \\
\hline Neryl acetate & 1361 & 1365 & - & - & - & - & $1.15^{*}$ & $1.92^{*}$ \\
\hline Geranyl acetate & 1366 & 1368 & - & - & - & - & $0.45^{*}$ & $0.70^{*}$ \\
\hline Eugenol & 1386 & 1378 & $11.39^{*}$ & $19.54^{*}$ & - & - & - & - \\
\hline Total & & & 72.98 & 78.32 & 85.30 & 92.95 & 6.59 & 11.43 \\
\hline \multicolumn{9}{|c|}{-- } \\
\hline$\alpha$-copaene & 1374 & 1374 & 0.28 & 0.27 & - & - & - & - \\
\hline$\beta$-bourbonene & 1382 & 1382 & 0.24 & 0.26 & - & - & - & - \\
\hline$\beta$-caryophyllene & 1416 & 1418 & 1.71 & 1.71 & - & - & 0.36 & 0.39 \\
\hline$\alpha$-bergamotene & 1435 & 1436 & 3.20 & 3.23 & - & - & $0.56^{*}$ & $0.63^{*}$ \\
\hline D-Germacrene & 1479 & 1479 & $6.98^{*}$ & $6.02^{*}$ & - & - & - & - \\
\hline$\beta$-bisabolene & 1510 & 1500 & - & - & - & - & 1.07 & 1.19 \\
\hline$\gamma$-cadinene & 1511 & 1512 & $1.52^{*}$ & $1.49^{*}$ & - & - & - & - \\
\hline$\delta$-cadinene & 1522 & 1525 & $0.21^{*}$ & $0.30^{*}$ & - & - & - & - \\
\hline Total & & & 14.04 & 13.28 & - & - & 1.99 & 2.21 \\
\hline \multicolumn{9}{|c|}{ 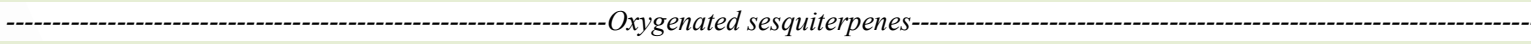 } \\
\hline$\alpha$-muurolol & 1641 & 1645 & $3.80^{*}$ & $5.64^{*}$ & - & - & - & - \\
\hline$\alpha$-cadinol & 1653 & 1653 & $0.22^{*}$ & $0.43^{*}$ & - & - & - & - \\
\hline Total & & & 4.02 & 6.07 & - & - & - & - \\
\hline Total oxygenated cor & & & 76.99 & 84.39 & 85.30 & 92.95 & 6.59 & 11.43 \\
\hline Total non oxygenatec & & & 23.01 & 15.61 & 14.70 & 7.05 & 93.41 & 88.57 \\
\hline
\end{tabular}

Results reported as mean of determinations $(\mathrm{n}=3)$; Means followed by *are statistically different (Student's $t$-test; P>0.05).

${ }^{1}$ Kovats' retention index obtained by GC-MS in this study using a RTX-5MS and a ZB-5MS column.

${ }^{2}$ Kovats' retention index values for all constituents obtained from literature (Adams, NIST, 2005). 


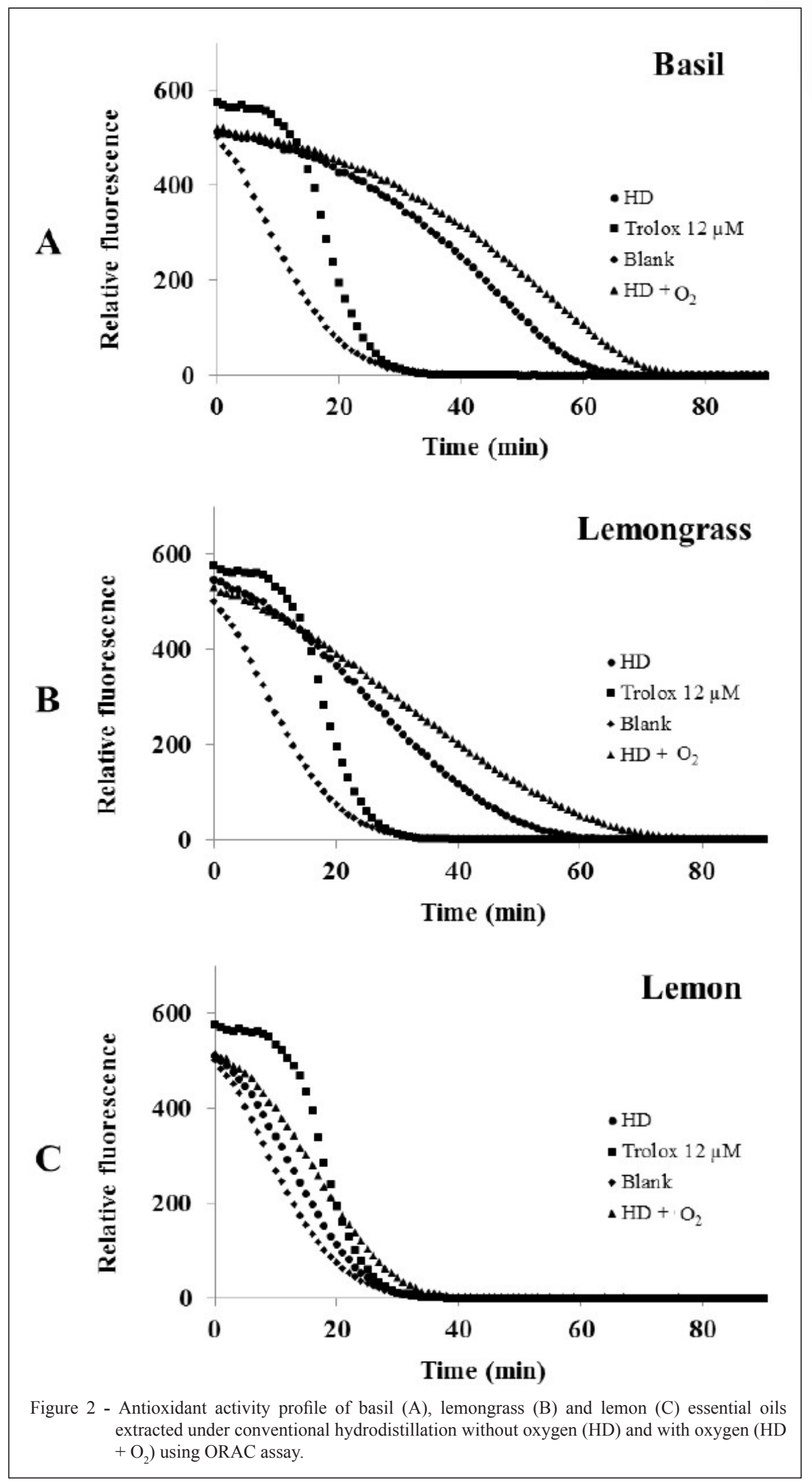

Ciência Rural, v.47, n.8, 2017. 
Trolox $\mathrm{g}^{-1}$ oil with oxygen addition, probably by the higher concentration of citral. Therefore, the antioxidant activity evaluation confirmed that changes observed in the chemical composition of oils extracted with oxygen improved the quality of essential oils obtained from the three plant materials evaluated.

\section{CONCLUSION}

The introduction of oxygen in the extraction of essential oils of basil, lemongrass and lemon peel lead to a higher amount of oxygenated compounds in the oil, mainly a rise in linalool, camphor, $\alpha$-terpineol, neral, geranial, eugenol and $\alpha$-muurolol. Antioxidant activity showed that the use of oxygen during extraction provided essential oils with more activity, explained by the increase in oxygenated terpenes. Taking into account these features, it was possible to conclude that the simple modification proposed in this study could be considered to be a suitable alternative to obtain compounds in the essential oil with higher antioxidant activity.

\section{ACKNOWLEDGMENT}

The authors are grateful to Coordenação de Aperfeiçoamento de Pessoal de Nível Superior (CAPES), Conselho Nacional de Desenvolvimento Científico e Tecnológico (CNPq) and Fundação de Amparo à Pesquisa do Estado do Rio Grande do Sul (FAPERGS) for supporting this study.

\section{REFERENCES}

ALFONZO, A. et al. Effect of the lemon essential oils on the safety and sensory quality of salted sardines (Sardina pilchardus Walbaum 1792). Food Control, v.73, Part B, p.1265-1274, 2017. Available from: $<$ http://www.sciencedirect.com/science/article/pii/ S0956713516306004>. Accessed: Jan. 03, 2017. doi: 10.1016/j. foodcont.2016.10.046.

AMORATI, R. et al. Antioxidant activity of essential oils. Journal of Agricultural and Food Chemistry, v.61, n.46, p.10835-10847, 2013. Available from: <http://pubs.acs.org/doi/abs/10.1021/ jf403496k>. Accessed: Jan. 03, 2017. doi: 10.1021/jf403496k.

BENTAYEB, K. et al. The additive properties of oxygen radical absorbance capacity (ORAC) assay: the case of essential oils Food Chemistry, v.148, p.204-208, 2014. Available from: <http:// www.sciencedirect.com/science/article/pii/S0308814613014714>. Accessed: Jan. 03, 2017. doi: 10.1016/j.foodchem.2013.10.037.

DJOUAHRI, A. et al. Effect of extraction method on chemical composition, antioxidant and anti-inflammatory activities of essential oil from the leaves of Algerian tetraclinis articulata (Vahl) masters. Industrial Crops and Products, v.44, p.32-36, 2013. Available from: $<$ http://www.sciencedirect.com/science/article/pii/ S0926669012005730>. Accessed: Jan. 03, 2017. doi: 10.1016/j. indcrop.2012.10.021.

DUARTE, A. et al. Antioxidant properties of coriander essential oil and linalool and their potential to control Campylobacter spp. Food Control, v.61, p.115-122, 2016. Available from: <http:// www.sciencedirect.com/science/article/pii/S0956713515302127>. Accessed: Jan. 03, 2017. doi: 10.1016/j.foodcont.2015.09.033.

GANJEWALA, D. et al. An update on bioactive potential of a monoterpene aldehyde citral. Journal of Biologically Active Products from Nature, v.2, n.4, p.186-199, 2012. Available from: $<$ http://dx.doi.org/10.1080/22311866.2012.10719126>. Accessed: Jan. 03, 2017. doi: 10.1080/22311866.2012.10719126.

GÜLÇIN, İ. Antioxidant activity of eugenol: a structure-activity relationship study. Journal of Medicinal Food, v.14, n.9, p.975-985, 2011. Available from: <http://dx.doi.org/10.1089/ jmf.2010.0197>. Accessed: Jan. 03, 2017. doi: 10.1089/ jmf.2010.0197.

MAISANABA, S. et al. New advances in active packaging incorporated with essential oils or their main components for food preservation. Food Reviews International, v.33, n.5, p.447-515. 2017. Available from: <http://dx.doi.org/10.108 0/87559129.2016.1175010>. Accessed: Jan. 03, 2017. doi: 10.1080/87559129.2016.1175010.

NGUYEN, H. et al. Effect of oxidative deterioration on flavour and aroma components of lemon oil. Food Chemistry, v.112, n.2, p.388-393, 2009. Available from: <http://www.sciencedirect. com/science/article/pii/S030881460800650X>. Accessed: Jan. 03, 2017. doi: 10.1016/j.foodchem.2008.05.090.

ORIO, L. et al. Hydrodistillation and in situ microwave-generated hydrodistillation of fresh and dried mint leaves: a comparison study. Journal of the Science of Food and Agriculture, v.92, n.15, p.3085-3090, 2012. Available from: <http://dx.doi.org/10.1002/ jsfa.5730>. Accessed: Jan. 03, 2017. doi: 10.1002/jsfa.5730.

OU, B. et al. Development and validation of an improved oxygen radical absorbance capacity assay using fluorescein as the fluorescent probe. Journal of Agricultural and Food Chemistry, v.49, n.10, p.4619-4626, 2001. Available from: <http://dx.doi. org/10.1021/jf010586o>. Accessed: Jan. 03, 2017. doi: 10.1021/ jf010586o.

PATEL, S. Plant essential oils and allied volatile fractions as multifunctional additives in meat and fish-based food products: a review. Food Additives \& Contaminants: Part A, v.32, n.7, p.1049-1064. 2015. Available from: <http://dx.doi.org/10.10 80/19440049.2015.1040081>. Accessed: Jan. 03, 2017. doi: 10.1080/19440049.2015.1040081.

TISCHER, B. et al. Effect of grinding method on the analysis of essential oil from Baccharis articulata (Lam.) Pers. Chemical Papers, v.71, n.4, p.753-761, 2017. Available from: < http://dx.doi. org/10.1007/s11696-016-0052-0>. Accessed: Apr. 15, 2017. doi: $10.1007 / \mathrm{s} 11696-016-0052-0$. 